\title{
Whistle-blowing by external auditors: seeking legitimacy for the South African audit profession?
}

Article

Accepted Version

Warren, M. and Solomon, J. (2014) Whistle-blowing by external auditors: seeking legitimacy for the South African audit profession? Accounting Forum, 32 (2). pp. 109-121. ISSN 0155-9982 doi:

https://doi.org/10.1016/j.accfor.2013.04.007 Available at https://centaur.reading.ac.uk/34160/

It is advisable to refer to the publisher's version if you intend to cite from the work. See Guidance on citing.

Published version at: http://www.sciencedirect.com/science/article/pii/S0155998213000161\#

To link to this article DOI: http://dx.doi.org/10.1016/j.accfor.2013.04.007

Publisher: Elsevier

All outputs in CentAUR are protected by Intellectual Property Rights law, including copyright law. Copyright and IPR is retained by the creators or other copyright holders. Terms and conditions for use of this material are defined in the End User Agreement.

www.reading.ac.uk/centaur 
Central Archive at the University of Reading

Reading's research outputs online 
Whistle-blowing by external auditors: Seeking legitimacy for the South African Audit Profession

\section{Warren Maroun}

\section{Jill Atkins}

\section{Accounting Forum}




\section{Abstract}

Auditing is often cited as playing an important role in managing agency-related costs and, accordingly, being integral to the sound functioning of capital markets. There may, however, be more to the attest function than simply a technical rational practice. By virtue of relying heavily on claims to technical expertise, professionalism, prudential judgement and public confidence auditing is both a source of legitimacy for organisations while, paradoxically, dependent on claims to legitimacy for its own continued existence. From this perspective, recent regulatory developments purportedly enacted to increase arms length control over the profession may not only be about improving perceived audit quality and practice but also about ensuring continued faith in the well-established 'rituals' of the assurance function. A reporting duty imposed on South African external auditors, akin to whistle-blowing, is used as a case study to explore this perspective. In doing so, this paper contributes to the scant body of interpretive research on auditing simultaneously offering one of the first insights into auditing regulation form an African perspective.

\section{Key words}

Auditing; Arms-length regulation; Legitimacy; Reportable Irregularity (RI); Section 45 of the Auditing Profession Act (the RI provisions); South Arica; Whistle-blowing 


\section{1: Introduction|}

Accounting has frequently been portrayed as a neutral means of collecting, analysing and reporting information to economic ends (Carruthers, 1995; Hopwood, 1987; Chandler et al, 1993). Similarly, auditing has been cast as part of the corporate governance machinery providing assurance on the fair presentation of financial statements to facilitate the sound functioning of capital markets (consider Watts and Zimmerman, 1983; Jensen and Meckling, 1976; Dart, 2011). As an integral part of the organisational landscape (see Peecher et al, 2007; Powell, 2010; Powell, 2007; Hopwood, 1987), accounting and auditing - and how these practices change over time - cannot, however, be ascribed solely to the drive for efficiency or profitability (see Baker and Owsen, 2002; Nel, 2001; Chandler et al, 1993; Hill and Jones, 1992; Burchell et al, 1980). To at least some extent, powerful institutional or social forces are also at work (Pentland, 1993; Pentland, 2000; Power, 1997).

Miller and O'leary (1987), Cowton and Dopson (2002) and Hopper and Macintosh (1993), for instance, provide an analysis of managerial accounting under a Foucauldian lens to illuminate a motif of disciplinary power at work in modern organisations. More broadly Carruthers (1995) posits that a political, social and intuitional forces underpin accounting in general, contrary to the economic focus of mainstream research. Fogarty (1992) and Hopwood (1987) provide comparable accounts.

When it comes to auditing, Power (2003) argues that the professional service is a largely socially constructed practice that is, paradoxically, both a source and in need of legitimacy (see also O'Dwyer et al, 2011; Unerman and O'Dwyer, 2004). Similarly, Humphrey and Moizer (1990) assert that, in addition to its 'techno-rational' purpose, auditing (specifically audit planning) serves an important ideological and marketing function. MacLullich (2003), using Foucault's 'technologies of the self' questions if the change to a risk-based form of audit can be explained, not only by a quest for more efficient and effective audit practice, but as powerful means of perception management designed to perpetuate belief in auditing 'rituals' (see also Power, 1994; Power, 1995; Pentland, 2000). By analogy, recent regulatory developments may have a similar institutional motif, contributing not only directly to audit quality (see, for exampleCullinan et al, 2012; DeFond and Lennox, 2011) but to the processes and techniques by which auditing preserves its claims to being a rational and legitimate part of capital markets.

Most of the work on auditing to date, particularly on audit quality and regulation, has, however, a strong positive focus (examples include Vakkur et al, 2010; Francis et al, 2005; Lesage and Wechtler, 2012). Despite the efforts of, inter alia, Power, Unerman, O'Dwyer and Humphrey, there is 
lack of critical or interpretive auditing research (Power, 2003; Khalifa et al, 2007; Humphrey, 2008). The result is that, relatively little remains known about the attest function, including regulation of the audit profession, beyond the narrow constructs of economic theory (Power, 2003; Humphrey, 2008)".

The aim of this research is, therefore, to provide an exploratory analysis of the role of external regulation of the profession under an institutional lens. Detailed interviews are used to provide a rich account of how external regulation may contribute to the perceived legitimacy of existing 'audit rituals' (Power, 1994). For this purpose, a duty to bring 'reportable irregularities' (RIs) to the attention of the Independent Regulatory Board for Auditors (IRBA) in South Africa (the RI provisions) is used as a case study. This duty, which may be loosely characterised as whistle-blowing, is in addition to the requirement to express an opinion on a client's financial statements ${ }^{i i i}$ (International Auditing and Assurance Standards Board [IAASB], 2009a; IAASB, 2009b).

The research considers how detailed $\mathrm{RI}$ provisions enshrined in statue may be interconnected with socially constructed 'ideals' of auditing and audit quality, and hence a source of pragmatic, moral or cognitive legitimacy (see Suchman, 1995). In doing so, the research provides an alternate perspective on the role of external regulation, simultaneously addressing the calls of Power (2003) and Humphrey (2008) for more field-work type studies into auditing practice. The research is also, possibly, one of the first interpretive study using the lens of intuitionalism to examine audit regulation from an African perspective (see Brennan and Solomon, 2008).

The remainder of this paper is organised as follows. Section 2 discusses legitimacy theory in brief and uses it to explain the shift from self to arms-length regulation of the audit profession in general. Section 3 elaborates on the method. Section 4 highlights how a relatively unique reporting duty imposed on the South African external auditor (Nel, 2001) may be an important source of legitimacy for the South African Audit Profession. Section 5 concludes. 


\section{2: Theoretical perspectives on legitimisation of external audit}

Legitimacy may be described as:

'a generalized perception or assumption that the actions of an entity are desirable, proper, or appropriate within some socially constructed system of norms, values, beliefs and definitions' (Suchman, 1995, p. 574) .

It is a subjective concept, interconnected with institutionalisation (Suchman, 1995; DiMaggio and Powell, 1983) and influenced by cultural and social variables including past experiences and how these are interpreted (Georgiou and Jack, 2011; Unerman and O'Dwyer, 2004; Power, 1995; Suchman, 1995; Llewelyn, 1996; Fogarty, 1992). The prior research identifies three 'sub-sets' of legitimacy.

Pragmatic legitimacy is rooted in an organisation's policies being perceived as valuable by constituents (exchange legitimacy) or responsive to their interests (influence legitimacy) (Suchman, 1995; Fligstein and Feeland, 1995; Meyer and Rowan, 1977; Georgiou and Jack, 2011; Ashforth and Gibbs, 1990; Fogarty, 1992). To some extent, organisations may also achieve dispositional legitimacy by being personified as 'moral', 'trustworthy' or 'socially responsible' (Suchman, 1995; 2010). Pragmatic legitimacy is, however, based largely on 'self-regarding utility calculations' (Suchman, 1995, p. 585) and can often be won by using tangible rewards.

In contrast, moral legitimacy transcends self-interest and emanates from being well placed within socially constructed value systems. Organisations are judged according to their accomplishments (consequential legitimacy); whether they are located in socially desirable sectors (structural legitimacy) and according to how they achieve their objectives (procedural legitimacy) (Suchman, 1995; Meyer and Rowan, 1977; Molm, 1986; Goldhamer and Shils, 1939; Abbott, 1981).

Finally, an organisation may be accepted as valuable or trustworthy on the basis of generally accepted belief, or 'taken-for-grantedness' (DiMaggio and Powell, 1983; Powell, 2007; Suchman, 1995; Meyer and Rowan, 1977). If an organisation's purpose is understood within a societal context, assumed comprehensibility affords legitimacy, especially when organisational accounts 'mesh both with larger belief systems and with experienced reality of the audience's daily life' (Suchman, 1995, p. 582; DiMaggio and Powell, 1983; Abbott, 1981). 


\section{Legitimacy theory, external audit and arms-length regulation of the audit profession}

Power (2003, p. 379) notes that: 'accounting systems, in their broadest sense, function often more to legitimate individual and organizational behaviour than to support efficient and rational decision making'. This sentiment echoes the theorisations of Meyer and Rowan (1977): that the emergence and development of organisations and institutions may be attributed, not only to economic rationality, but to a complex process whereby formal rational or institutional structures are used to afford a sense of credibility or legitimacy. From the perspective of the audit profession the same applies. linstitutionalisation of audit practice becomes a powerful source of legitimacy for the independent attest function (Pentland, 2000; Power, 1997; Power, 1994).

By standardising accounting practice (IAASB, 2009d; Power, 2003; Power, 1995); codifying informal procedures (IAASB, 2009c; Power, 1995; Hopwood, 1987);becoming a repository of technical expertise (Power, 1994; Humphrey and Moizer, 1990); appealing to the ideal of serving the public interest by attesting to the fair presentation of financial statements (IAASB, 2009a; Watts and Zimmerman, 1983; Power, 1994; Mosso, 2003); encouraging the recruitment of cosmopolitan workers (Chandler et al, 1993; Edwards, 2001; Burchell et al, 1980); and establishing a formal autonomous role for accounting and auditing (Burchell et al, 1980; Hopwood, 1987; Cooper and Robson, 2006) professionalization of accounting and auditing systems entrenched motions of pragmatic and moral legitimacy. At the extreme, these professionals came to be seen as a class of 'gentlemen', highly skilled and beyond reproach (Edwards, 2001; Zeff, 2003a; Wyatt, 2004), possibly signalling the achievement of cognitive legitimacy (consider: Power, 1994; Humphrey and Moizer, 1990). The result is that a modern capital market without an independent external audit function has become almost unimaginable (see Power, 2003; Power, 1994; King-III, 2009; Solomon, 2010).

Legitimacy is not, however, static (Power, 2003; Suchman, 1995; Rodrigues and Craig, 2007). The accounting profession like any other, is build on the trust vested in it by society (Unerman and O'Dwyer, 2004; O'Dwyer et al, 2011; Power, 2003; South African Institute of Chartered Accountants [SAICA], 2012) and as such, seeks to preserve its claims to legitimacy to ensure continued existence. In this respect, a self-regulatory approach has proved instrumental in reassuring constituents of the credibility of the external audit process (see Zeff, 2003a; Shaked and Sutton, 1981; Edwards, 2001). Peer reviews to ensure high quality audit engagements (see Carcello et al, 2011; Malsch and Gendron, 2011); the development of codes of conduct (examples include SAICA, 2012; International Federation of Accountants [IFAC] 2006); controlling entry to the profession through formal examinations (Low et al, 2008) and continuous revision of technical standards (for examples see Financial Reporting Council [FRC], 2011; IAASB, 2012; Barth, 2008; International 
Accounting Standards Board [IASB] 2009) are examples of the largely self-regulatory measures that have, historically, been integral to maintaining the legitimacy of the audit and accounting profession.

Under a banner of self-regulation, a legitimacy reserve (see also Ashforth and Gibbs, 1990; Edwards, 2001; Suchman, 1995) has resulted meaning that isolated issues have not lead to a material threat to the profession's standing. Faced with a corporate failure, the profession has been able to create an effective 'firewall' between challenges to previously won legitimacy and the ongoing 'essence' of the institution (see Suchman, 1995; Zucker, 1986). For example, assumed deficiencies have been successfully ascribed to a misunderstanding of the scope of external audit by constituents and responded to with calls for educating users about the nature and purpose of the attest function (Gold et al, 2012; Sikka et al, 1992; Fogarty et al, 1991). In other instances, the profession has reviewed its independence protocols (Wines, 2012; European Commission, 2010; Dart, 2011), bolstered quality review processes (FRC, 2010; FRC, 2008; Nel, 2001; Carcello et al, 2011) and revised professional standards (see Byington and Sutton, 1991; IAASB, 2012) with an aim to demonstrating its commitment to high quality audit practice and preserving its legitimacy.

Repeated failures and corporate scandals can, however, begin to 'deplete' an institution's legitimacy reserve (see Suchman, 1995). They signal to users that automatic or taken-for-granted belief in the sound functioning of the audit system may be unfounded (Unerman and O'Dwyer, 2004; Wines, 2012). Unerman and O'Dwyer (2004), for example, exploring the demise of Arthur Anderson, argue that the collapse of Enron lead to a widespread withdraw of trust from the expert system, with the result that a corporate scandal - initially limited to only a single organisation and its auditor - soon had implications for the legitimacy of audit profession (and its self regulation franchise) on a global level.

Mounting cynicism lead to self-regulatory efforts following the demise of Enron becoming increasingly ineffective (see Mosso, 2003; Zeff, 2003b; Bazerman and Moore, 2011). Unerman and O 'Dwyer (2004) describe how non-expert users of audit reports develop a new-found appreciation for the fallibility of external audit and limitations of the profession's review and quality controls processes. Pesqueux (2005) provides a critical perspective of corporate governance systems whereby self-regulation may be seen as mere symbol used to conjure up procedural legitimacy but lacking in substance (see also Fuerman, 2004; Edwards, 2001). More critical still, the profession may be seen as exerting economic and political power in pursuit of self-gain with little regard for its stated objective of serving the public interest (consider Baldvinsdottir et al, 2009; Low et al, 2008; Marnet, 2007; Pesqueux, 2005; Zeff, 2003a; Power, 1994)iv. 
Accordingly, the efforts of the profession alone to respond to various corporate failures, and more recently the global financial crises, are not enough (Carcello et al, 2011; Bayou et al, 2011; Cagnin et al, 2011; Odendaal and De Jager, 2008; Riotto, 2008; Unerman and O'Dwyer, 2004).. Delegitimized structures are, therefore, 'quarantined' and monitors put in place by independent regulators to prevent subsequent failures (Suchman, 1995). The promulgation of SOX, with mandatory audit quality provisions (Riotto, 2008; Sy and Tinker, 2008; Bronson et al, 2011; Cullinan et al, 2012); formation of the PCAOB (Mosso, 2003; Kaplan and Williams, 2012), revocation of Author Anderson's license (Unerman and O'Dwyer, 2004); and calls for separation of non-assurance practice from existing audit firms (Wines, 2012; Bazerman and Moore, 2011; European Commission, 2010) serve as examples. In summary, in the USA, UK, France, Italy, Austria, Canada, Germany, Australia and New Zealand, governments and regulatory bodies are responding to a perceived crisis of legitimacy in the audit profession by moving away from a system of self-regulation to one where audit practice is increasingly subject to exogenous control (Bronson et al, 2011; European Commission, 2010; Canada et al, 2008; Laughlin, 2007; Nel, 2001; Konar et al, 2003; Kaplan and Williams, 2012).

\section{South Africa's reportable irregularity provisions}

South Africa was not insulated from a host of domestic and international corporate scandals. The Minister of Finance (Manuel, 2002) noted:

\footnotetext{
'The issue of corporate governance and in particular the role of the auditing firms has once again dominated the headlines. The Enron debacle has brought into sharp relief a number of key issues weak or non-existent governance structures...ineffective auditing, independence of auditors and conflicts of interest arising from inadequate separation between auditing and consultancy. Closer to home a number of corporate failures...have raised a similar set of issues'
}

In this context several reforms were introduced similar to those seen under SOX (Konar et al, 2003; Maroun, 2012; Maroun and Segal, 2011). For example the Public Accountants' and Auditors' Board (PAAB) had been responsible for, inter alia, the review of audit engagements for compliance with professional auditing standards since promulgation of the Public Accountants' and Auditors' Act (1951) (PAAA) in 1950s. Due to concerns over a lack of independence (see also Church and Shefchik, 2011) the body was replaced by the IRBA when the PAAA was superseded by the Auditing Profession Act (2005) (APA) in 2005 (Konar et al, 2003; Negash et al, 2003). To further signal a mover away from the traditional model of self-regulation (Odendaal and De Jager, 2008), amendments were proposed to company law that would address, inter alia, the matter of auditor rotation and the need for mandatory appointment of audit firms by audit committees rather than directly by a client's management body (Companies Act, 2008). Of particular relevance for the 
purpose of this research was the entrenchment of what may be loosely described as a whistleblowing duty for the South African external auditor".

The PAAA is the genesis of the South African auditor's mandatory duty to bring certain transgressions, then 'material irregularities' (MIs) to the attention of the PAAB (s20(5) of the PAAA, 1951; PAAB, 2003; Dunn et al, 1989). This act provided that:

\begin{abstract}
'If any person acting in the capacity of auditor to any undertaking is satisfied or has reason to believe that in the conduct of the affairs of such undertaking a material irregularity [MI] has taken place or is taking place which has caused or is likely to cause financial loss to the undertaking or to any of its members or creditors, he shall forthwith dispatch a report in writing to the person in charge of that undertaking giving particulars of the irregularity....' (s20(5)a of the PAAA).
\end{abstract}

Having issued the initial report,

'[unless] within 30 days after an auditor has dispatched such a report, he has been satisfied that no such irregularity has taken place or is taking place or that adequate steps have been taken for the recovery of any such loss so caused or for the prevention of any such loss likely to be so caused, he shall forthwith furnish the [PAAB] with copies of the report and of any acknowledgement of receipt thereof and reply thereto and such other particulars as he may deem fit' (s20(5)b of the PAAA).

In 2001, the Commission of Inquiry into the Affairs of the Masterbond Group and Investor Protection in South Africa (Nel, 2001), proposed a number of refinements to this whistle-blowing duty. In 2005 s45 of the APA replaced s 20(5) of the PAAA. Auditors would now be required to inform the IRBA of 'reportable irregularities' (RIs) (s1 and s45 of the APA, 2005).

Briefly, any 'unlawful act or omission' by a person responsible for a client's management ( $\mathrm{s} 1$ of the APA, 2005) (its management board) which has caused or is likely to cause material financial loss to different stakeholders; amounts to a material breach of fiduciary duty; or is an act of theft or fraud, must be reported 'without delay' to the IRBA (s45 of the APA, 2005; IRBA, 2006). Like the PAAB, the IRBA is empowered to inform appropriate regulators of the respective irregularity (IRBA, 2006; PAAB, 2003). The reporting duty under s45 of the APA is largely consistent with that under the repealed s20(5) of the PAAA (Wielligh, 2006; Gawith, 2006; PwC, 2006). Three important differences expanding the scope of the reporting duty should, however, be noted.

Firstly, the auditor suspecting a MI was required to initially notify the client. It was only, within 30 days after informing the client, that the PAAB was notified of the irregularity and then only if the client had not responded appropriately to the respective transgression (PAAB, 2003; Dunn et al, 1989). Fearing that auditors' professional judgment could lead to inconsistent application of the whistle- 
blowing duty, or that auditors and clients would use the 30 day period to circumvent the need for the reporting, the 30 day window period was dispensed with in favour of reporting 'without delay' (Nel, 2001; Gawith, 2006; Wielligh, 2006). Therefore, within three days of the IRBA being informed (and not before) the auditor must notify the client of the suspected RI and afford the management board a reasonable opportunity to discuss the first report with the auditor (s45(2) of the APA, 2005). In addition, a second report sent to the IRBA - 30 days after the first report - is now more informative, divulging that either: no $\mathrm{RI}$ occurred; an $\mathrm{RI}$ did occur but has been remedied; or that the $\mathrm{RI}$ is continuing (IRBA, 2006).

Secondly, it was resolved that any act of theft or fraud involving those responsible for the management of the client, irrespective of perceived materiality, would be reported to the IRBA (PwC, 2006; IRBA, 2006). This was despite the possibility of proliferation of clearly trivial reporting (SAICA, 2001 cited in Nel, 2001; Wielligh, 2006) which the legislature felt would be outweighed by the added benefit of more frequent whistle-blowing (Nel, 2001). Similarly, while breaches of fiduciary duty and acts or omissions leading to financial loss would continue to be reportable only if material, these losses or breaches need not only be suffered by 'members or creditors' of the audit client to be reportable (s20(5) of the PAAA). The effects on a 'partner, member, shareholder, creditor or investor' would now also have to be considered ( $\mathrm{s} 1$ of the APA) thereby further broadening the reporting duty (see: Wielligh, 2006; PwC, 2006; IRBA, 2006). Finally, s20(5) of the PAAA usually applied only in cases where the auditor was acting in the capacity of an auditor to any undertaking (PAAB, 2003). Under s45 of the APA, this is not necessarily the case with the result that more frequent whistleblowing may occur (IRBA, 2006).

In this way, the APA marked the entrenchment and widening of the auditor's whistle-blowing duty (Nel, 2001; Wielligh, 2006 SAICA, 2001 cited in Nel, 2001). The South African Government feared that the historically low volume of Mls being reported to the PAAB were indicative of ineffective whistle-blowing policies that could be enhanced if the reporting duty was broader (Manuel, 2002; $\mathrm{Nel}, 2001)$. It would then be left to an independent regulator to conclude on whether or not the irregularity ought to be brought to the attention of the relevant third parties, rather than leaving this decision in the hands of the individual auditor (Nel, 2001). As such, it was hoped that 545 of the APA would improve the quality of reporting by auditors; enhance a sense of transparency and accountability; and ultimately contribute to the standing of the South African Audit Profession (see also Negash, 2004; Negash et al, 2003; Konar et al, 2003). 


\section{3: Method}

Studies examining the relationship between auditing and social constructs of legitimacy are scare (Power, 2003; Humphrey, 2008). For this reason a qualitative approach using detailed interviews grounded in an interpretive epistemology is employed. (consider: O'Dwyer et al, 2011; Brennan and Solomon, 2008).

Using semi-structured interviews, this research focuses on the perspectives of those who are directly involved with audit and have been contributing to the development of audit practice in South Africa. Respondents included audit partners from the Big Four, as well as second tier audit firms, with at least five years experience in their role as 'engagement leaders' (IAASB, 2009c) (experts). Informed users of audit reports serving at institutional investors, on audit committees or at regulatory bodies also participated in the research (users) ${ }^{1}$. The result is that some of the most influential and knowledgeable individuals on the issue of audit practice and quality in South Africa were engaged, contributing to the validity and reliability of the findings (see also: O'Dwyer et al, 2011; Creswell, 2009).

\section{Data collection}

Respondents were contacted by telephone or by email. They were invited to participate in the research, an interview time was set, and an agenda with several open-ended questions dealing with the operation of the RI provisions and the contribution it makes to the perceived legitimacy of the audit profession was provided. Thirty interviews of between 45 minutes and three hours were conduct in Johannesburg, Cape Town and Pretoria between 1 May 2011 and 1 June 2012. Prior to this, the agenda was piloted during March 2010 with ten audit managers and three academics at one of South Africa's Big Four audit firms and two leading South African universities respectively.

At the start of each interview, respondents were reminded of the nature and purpose of the research and that there were no 'correct' or 'incorrect' answers. They were assured that the research was carried out for academic reasons only and that their responses would be treated as strictly confidential. Individual participation consent forms were completed, which included granting permission for the recording of interviews. (All interviewees consented with the exception of two, where the researcher maintained detailed field notes during the course of the interviews.)

\footnotetext{
${ }^{1}$ The research uses 'U1-13' and 'E1-16' to identify the user and expert interviewees respectively.
} 
The interview agenda was used to loosely guide the interviewee. This allowed the interview process to be relatively unstructured to ensure detailed discussion while retaining focus on the purpose of the research. Questions were, to the extent possible, neutral and non-leading (Creswell, 2009). At the same time, respondents were, on occasion, asked to explain a particular concept or statement in different words or from different perspectives to address 'script coherent expressions' or resolve any ambiguities (Alvesson, 2003). The tone was professional and non-intrusive. Although the sequence in which the issues were addressed - as well as the detail provided by each respondent - varied, the same themes were covered during each interview and the same point was used to commence each interview, namely: a brief discussion on the purpose of the RI provisions (adapted from O'Dwyer et al, 2011).

\section{Data analysis}

Data analysis was by means of a 'data analysis spiral' (Leedy and Ormrod, 2001; Rowley, 2012). Electronic recordings were transcribed and additional embedded comments added as soon as possible after the interview was completed. This included notes on areas for probing either in followup sessions or other interviews (as per O'Dwyer et al, 2011). Recorded interviews were perused to gain a sense of the content and initial conceptualising and cataloguing took place using manual notes (Leedy and Ormrod, 2001, p. 153).

Initial notes were contrast and general themes, categories and interconnections were identified and aggregated using a 'data mind map' (adapted from Leedy and Ormrod, 2001; Holland, 1998a; Holland, 1998b; Oakes et al, 1998). Content was organised initially under headings and subheadings (axial codes) consistent with each of the 'subsets' of legitimacy identified by Suchman (1995) and discussed in Section 2. Reclassifications were made as necessary as new information emerged from either additional interviews or the literature.

Defining axial codes afforded as sense of structure and allowed the study to remain focused but did not detract from the iterative and exploratory nature of the research. Specific themes and concepts emerging during the course of the interview and analysis process drove the development of subcategories or open codes. Notes on the different phrases, principles and concepts were made on each transcript and used to summarise data. These were numbered and cross-referenced to a 'code register' or 'legend' to allow for easy data analysis. The product was a 'summary table' (O'Dwyer et al, 2011) for each transcript which 'assigned' the transcript content to 'pools', each of which are grouped under the axial codes (adapted from: O'Dwyer et al, 2011; Creswell, 2009; Leedy and Ormrod, 2001; Parker and Roffey, 1997; Rowley, 2012). 
Inspired by a grounded theory approach, initial data collection was complemented by follow up sessions. Questions were posed either telephonically, by email or during additional interviews depending on ease of access, participants' time restrictions and budgetary limitations. Data accumulation and analysis was carried out as discussed above. This approach allowed for clarification of points and for respondents to elaborate on key arguments, counterarguments or ambiguities emerging during the initial round of interviews. The researchers sought to gain a sense of 'saturation' of the topics discussed rather than a measure of consensus and, thus, only a limited number of follow-up questions were raised. This is an inherent characteristic of the chosen methodology and not a threat to validity and reliability (for example: Creswell, 2009; Quattrone and Hopper, 2005). Rather, the approach is inspired by a 'reflexive pragmatism' in the sense that, while different perspectives are explored, practically, 'endless reflexivity' needs to be balanced in the name of 'direction and accomplishment' (Alvesson, 2003, p. 14). It should be noted that the findings and substance of initial interpretations was not altered by the follow-up sessions (see also: O'Dwyer et al, 2011; Ahrens et al, 2008; Ventovuori et al, 2007; Oakes et al, 1998)

\section{4: Discussion}

\section{1: Pragmatic legitimacy: audit as an example of whistle-blowing}

Experts unanimously agreed that the RI provisions did not change the fundamentals of audit, a finding consistent with the fact that the legislation does not impose a duty on auditors to actively seek out RIs (see: IRBA, 2006) ${ }^{\mathrm{Vi}}$. As a result,

'the fact that you have a duty to report an irregularity does not make audit more or less legitimate and so, if you were to delete $\mathrm{s} 45$ [of the APA] you would still have the same perceived value' (U4).

Not all users and experts, however, shared this view. Several argued that the RI provisions are an important part of the audit reporting framework and, thus, a possible source of legitimacy. User 2 explains:

'The big issue with audit has always been whether or not it adds value. For the big listed companies the theoretical argument is that audit does add value because the auditor reports to the shareholders on the reliability of the financial statements but...I guess for a lot of people...audit is 
really a grudge purchase. Adding RIs on top of that at least gives [... ] a bit more. I am not sure that significant value has been added but [the auditor] has at least added something' (U2)

The RI provisions do not impose a duty on the auditor to detect fraud. What is, however, achieved is added 'depth' to what is reported (E13), which is interpreted as improving transparency at both the client and audit level and being responsive to the larger interests of user-groups (consider also: Georgiou and Jack, 2011; Solomon, 2010). As summarised by User 2 and 13:

\begin{abstract}
'At the end of the day, shareholders - and I suppose other people as well - have a right to know. If you have invested money in a company or are doing business with them or even if you just rely on that particular company, you have a right to know if there are any anomalies. That's one of the main themes coming out of the codes of governance and the whole integrated reporting project. Now what the RIs are doing is creating a duty on the auditor to do more than just issue a generic audit report. The legislature is taking cognizance of the needs of different parties to be made aware - through the functioning of the IRBA - of irregularities. So, in that way, s45 [of the APA] is basically a type of whistle-blowing platform that is responding to the demands for better audit reports and for enhanced transparency and accountability on the part of corproates' (U13).

'Section 45 [of the APA] may not be perfect... [but], there is at least a perception that the auditor has a duty to report. What happens to the report once sent to the IRBA, that's a different issue. But at least there is a perception that the auditor has a duty to report under the legislation. And it's not limited to just financial statements' (U2).
\end{abstract}

What most users, as well as the European Commission (2010a; 2010) and IAASB (2012) highlight is the difficultly of demonstrating the value added by audit due to the generic nature of the audit report and opaqueness of the audit process (see also: Humphrey and Moizer, 1990; Power, 1994). The RI provisions' legitimising potential may, in this context, be derived from the production of tangible reports offering specific details on irregularities that would otherwise not have been in the respective regulatory or public domain.

The whistle-blowing duty found in s45 of the APA, by virtue of its potential to bring transgressions into the open, thus, adds tangible value for different stakeholders. The RI provisions effectively constitute a type of 'whistle-blowing' discourse (E16), that forms part of a broader social milieu where almost all respondents pointed to enhanced reporting as a favourable requirement (see also Khalifa et al, 2007).In other words, the whistle-blowing duty reflects normative values and perceived social interests that associates the act of reporting with enhanced transparency and accountability (U2; U12; E16), improved financial reporting (E9; E17; U13) and, ultimately, an important source of legitimacy. 
Users 1, 2 for example, suggested that RIs could, depending on their nature, be useful for the JSE in monitoring compliance with its listing requirements and protecting investors. User 3 and Expert 7 described how Rls could be used by both the taxation and company regulatory authorities to monitor and enforce compliance with respective legislation. More broadly, Nel (2001) makes a general case for whistle-blowing by auditors, stressing the benefits that may be realised for society as a whole if transgressions are actively reported by auditors, a sentiment echoed by the European Commission (2010a; 2010), IAASB(2012) and CESR (2007), all of whom are championing improved reporting guidelines for the audit profession (see also Solomon, 2009; IRC, 2011).

Although some experts highlighted the possibility of the RI provisions leading to over reporting because of the duty to report any act of fraud or other defined irregularities 'without delay', two interesting counterarguments were raised. Firstly, that the legislation favours prompt reporting, and that only a fraction of Rls may be highly relevant, was perceived as having confirmatory value and, thus, a source of exchange legitimacy. As explained by User 3,

'the nature of reports serves to confirm (or at least give the impression) that 'our systems are working, otherwise we would have more Rls being issued' (U3).

Secondly,

'far better to leave the legislation as is and have a hundred minor issues get reported with just one big one than to tone [the reporting duty] down and run the risk that the next significant issue does not get reported' (E16).

'If you look at the RIs (the stats) - a lot of it is actually quite trivial.....[The reports] are telling you that this or that register is out of date or that something is outstanding' (U2). 'Is this a total waste of time? I suppose you could argue that it is, but then again, there is method to this. It lets the clients know that things get reported, even if otherwise immaterial, and that definitely keeps them on their toes. There is no scope for hiding behind materiality to avoid the auditor reporting' (E16). The result is that the current functioning of the RI provisions, 'almost pushes [audit clients] to do a little bit more because they do not want to get themselves in trouble - they don't want a RI to be reported' (U2)

'And finally, just remember that because you think something is immaterial does not mean that other people will. You set a precedent by doing that and before long, who knows what ends up not being reported' (E17).

In its current form, 'the 'marginal benefits of the legislation are, therefore, probably exceeding the marginal costs' (U2). By erring on the side of side of prudence, and requiring more active whistleblowing (E14; E17), the legislation was perceived as adding to a culture of reporting and addressing 
the risk that professional judgment of the auditor could lead to an irregularity, significant from the perspective of different stakeholders, not being reported. In other words, the RI provisions were perceived by most respondents as taking cognisance of the needs of diverse stakeholder groups, each of whom may have different views on the value of what is reported and on what ought to be reportable in the first place.

Following from this, that the $\mathrm{RI}$ provisions are formalised added to the sense of exchange and influence legitimacy by achieving an 'ordered' (E9) and 'rational' (U2) approach for discharging the whistle-blowing duty. Consistent with the prior literature, for whistle-blowing to be effective and yield dividends for stakeholders, clearly defined reporting channels are needed and uncertainty over when to report must be addressed (Seifert et al, 2010; Nam and Lemak, 2007; Miceli and Near, 1984; Near and Miceli, 1995). According to users, this is achieved by the APA defining 'irregularities' and prescribing the reporting process, complemented with additional formal guidance made available by the IRBA (2006). The result is that users felt that the reporting duty was a bona fide one, allowing the auditor to add real value by enhancing the quality of what is reported (U12; U13). The legislation, coupled with the IRBA's (2006) guide on RIs, was cited as providing 'added certainty on when and how to report' (U12), highlighting that the reporting requirement was 'capable of practical implementation' and, accordingly, a means of adding to the 'credibility' or 'reporting value' of the audit process (U13).

What also bolstered users' favourable impression of the auditor was the ability of the RI provisions to serve as an independence safeguard. The prior literature offers several accounts of growing concerns about auditors' independence in both fact and appearance due to, inter alia, economic dependence on the client (for examples see Dart, 2011; Wyatt, 2004; Low et al, 2008). As explained:

'The reality is that in any business, you've got relationships with your different stakeholders. One of those relationships is with your customer. Now... what you try to do all the time... is protect that relationship. You need to make sure that that relationship is protected, whatever the cost, right? Now, we've got a set of regulations that require us to do something which is quite unnatural in the normal business relationship. In a normal business relationship, where you find that there is something which is wrong, you go and speak to the customer and [come up] with some sort of agreement and you sort it out. Now this is not the case. However, our job is [to be the] auditors and the basis of everything that we do is ethics. So what the legislation has done - is that it's made us more aware of what "ethics" means and what it means "to be ethical"' (E3).

By creating a duty to report certain client transgressions, s45 of the APA 'drives home' the duty of the auditor to 'serve as a watchdog' (U2) and, coupled with that, the importance of independence of fact and appearance (U12). 
Although not all experts shared this view, most agreed that, at the very least, the RI provisions can aid in resolving a tension between owing a professional duty of confidentiality to the client (IAASB, 2009a) and being obliged to serve the public interest by bringing potentially materially transgressions into the open ( $\mathrm{Nel}, 2001)$.

'In any relationship...between yourself and the client, invariably you are going to get to a point where you are in a tight corner. And when you're in that tight corner, you need avenues to get you out of there. Almost like an escape hatch. And this legislation might be that escape hatch' (E3).

'When they found something wrong, [auditors] wanted to know how to report it without effectively "ratting out the client".... when I am obliged to [report] at least I can say I was forced into it. So the legislation is a nice "escape valve"' (U1).

Just as professional standards become a means of legitimising certain audit processes by allowing the auditor to 'throw the book at the client' (Humphrey and Moizer, 1990, p. 226), so the RI provisions provide a means of justifying reporting a client's transgressions to third parties. For users, this provided further evidence that the reporting duty was a viable one, able to improve the scope and value of the audit process and, hence, its pragmatic legitimacy.

Concurrently, several users felt that necessitating that any act of fraud (as opposed to quantitatively material fraud only), be reported 'without delay', (see Section 2), addressed the concern that heuristics (consider: Owhoso and Weickgenannt, 2009; Ashton, 1992), self interest threats or pressure from clients (see: SAICA, 2012; Windsor and Warming-Rasmussen, 2009; Wyatt, 2004) could lead to auditors avoiding reporting even if contrary to the public interest. Although respondents did not cite specific examples of such an issue, what may be important to achieve pragmatic legitimacy is the absence of negative experiences rather than 'the presence of positive achievements' (Georgiou and Jack, 2011, p. 321). Favouring broad reporting was thus seen as a type of preventative measure to safeguard effective whistle-blowing, reinforcing respondents' notions of a policy in line with broader interests of diverse stakeholder groups (E17; U12).

Complementing this is the partial deferral of the whistle-blowing decision to the IRBA. Several users, suggested that the move to couch the whistle-blowing duty in legislation, rather than as a professional requirement, becomes an important means of entrenching the notion of adopting constituents' standards as one's own (Suchman, 1995) by recognising the limitations of a self regulatory approach post Enron et al (E4, E8, E17) As summarised by Expert 3:

'The whole concept of self-regulation I never quite understood because you end up with a situation where people just get together and form these rules which they can easily amend now and again 
when they feel like it. I don't think that that is necessarily the right answer. I think we need to strike a balance between self-regulation and demonstrating a commitment to users of the audit reports. On top of that, I think it's nice to have a separate body which we report [RIs] to because when you get difficult questions that you need to answer, you need somebody who is independent - who is going to be out of the situation - making a decision. So for that reason, I think it is good that we have an independent body' (E3).

'That not only assists with resolving technical difficulties with regards to s45 [of the APA] and with ensuring that conclusions are both in line with the legislation and not affected by relationships between the auditor and the client, it also shows users that we have been listening. After Enron and everything else that has been going on, people want auditors to be more regulated and to defer some of the difficult decisions to an independent regulator. By following these requirements, we are demonstrating that we don't just put our heads in the sand and hope people with think better of audit in the future. We now have the IRBA, which is much more independent of the profession than the PAAB was, that is involved in deciding what issues auditors have reported get escalated to the relevant people' (E17).

As put by Suchman (1995, p. 578), 'the surest indicator of ongoing commitment to constituents' wellbeing is the organization's willingness to relinquish some measure of authority to the affected audience'. In this case, authority under a traditional self-regulatory approach (Odendaal and De Jager, 2008) is relinquished to regulation under the banner of the independent IRBA. As explained by several experts, this move towards more arms-length regulation becomes an important means of reassuring users that the audit profession is cognisant of the concerns raised about self-regulation (for examples, see Bazerman and Moore, 2011; Pesqueux, 2005; Mosso, 2003; Zeff, 2003b). By complying with s45 of the APA experts, in general, argued that this subtly signalled the continuing commitment to secure the confidence of stakeholders, including clients (see also: Nel, 2001; Unerman and O'Dwyer, 2004). In other words, by adopting a type of conformist strategy (Suchman, 1995; Meyer and Rowan, 1977), whereby auditors are seen to comply with the RI provisions regarded by constituents as a means of enhancing the financial reporting process (U12; E6) - a sense of legitimacy results.

To elaborate, Experts 5 and 8 explained that compliance with legislation has the potential to damage client relations to the detriment of the respective engagement's profitability. On the one hand, fines and imprisonment are possible reasons for not disregarding the duties enshrined in $\$ 45$ of the APA. On the other hand, the opaqueness of the audit process (Power, 1994) suggests that, theoretically, it would be possible for auditors to simply ignore their reporting duty and avoid material sanctions by virtue of a low detection risk (E1; U8). In this context, when asked why auditors comply with the RI provisions experts often highlighted the importance of maintaining expectations. As explained by Expert 3 and 7: 
'I think you need to have the reporting requirement because the market clearly wanted to have something in place' (E 3) and 'at the end of the day, [when talking about blowing the whistle] that is the purpose of the auditor...shareholders are looking to you to play a certain role' (E7).

Responding to the question of whether or not informed users would think less of auditors in the absence of the RI provisions, User 2, for example, stated: 'definitely- because of the expectation that people have of the auditor as a watchdog!' Accordingly, references by experts to maintaining professional standards (E4; E5; E10); the good name of the profession (E4; E7); the image of the firm (E5; E9), and the trust of shareholders (E5; E8: E12) highlights an awareness of the importance of auditor legitimacy. Although the auditor may be able to disregard the reporting duty with sufficiently low probability of being sanctioned by the IRBA (E5; E11; U1; U7), conformance with the expectation that the auditor 'is a watchdog' allows the auditor to internalisation pragmatic legitimacy associated with the RI provisions. This is extremely valuable if audit may be regarded as a 'grudge purchase' (U2) and with users unable to directly observe the audit process (see also: Meyer and Rowan, 1977; Power, 1994; Power, 1995). As summarised by User 1 and 13:

'I don't think that [auditors] would wilfully....[circumvent their reporting duty]. I don't think that that occurs to them. The IRBA would never know but there is a general risk from outsiders' (U1). 'They have a piece of legislation that tells them what society expects and they seem to be aware of the importance, as professionals in whom we place our confidence, of meeting these expectations; of conforming with society's regulations and, hence, its desires' (U13).

Elaborating on this User 3 and Expert 16 felt that:

'If [the failure to comply with the whistle-blowing duty] gets out, that auditor is finished' (E3). 'Yes, they might get sued by someone but whether that happens or not, he did not live up to expectations and he has zero chance of being trusted. That auditor has lost all credibility. He has zero standing because he has ignored the duty he owes to people other than himself' (E16).

As explained by Carrington (2010), the IFAC (2006) and Edwards (2001), professional appearance and behaviour are at the heart of the audit process. The RI provisions are interconnected with this. Conformance with the reporting duty is a means of meeting users' expectations; of signalling professional behaviour, trustworthiness and value-adding conduct; and hence adding to perceptions of pragmatic legitimacy.

Respondents, therefore, confirm the findings of Suchman (1995:587): to achieve pragmatic legitimacy the perceived needs of constituencies need to be met. Mandated whistle-blowing - initially under s20(5) of the PAAA (1951) - addressed the general expectation that auditors ought to divulge more than just in terms of the formal audit report (consider: Nel, 2001; European Commission, 2010; 
Manuel, 2002; IAASB, 2012). Continuation of this reporting duty under the APA (2005) is consistent with the current trends pointing to the value of additional reporting by auditors (see, for example, KPMG, 2010; European Commission, 2010a; European Commission, 2010; Deloitte, 2010) and whistle-blowing in general (see Seifert et al, 2010; Vinten, 2003; PwC, 2011b).

\section{2: Whistle-blowing giving rise to moral legitimacy}

There may be more to whistle-blowing by external auditors than simply material benefits for constituents. Users, in particular, point to the possibility of whistle-blowing being 'the right thing to do' (U2). Concurrently, the RI provisions were associated with audit being akin to 'a watchdog that is meant to bring transgressions into the open' (User 3). A sense of moral duty and societal awareness are interconnected with this (see also Hwang et al, 2008; Vinten, 2000). User 2 elaborates:

I think whistle-blowing is very important...Generally, any responsible citizen has got a duty to flag something that they think is wrong....and if you don't have that in society, then morally, things begin to degenerate. [That means that] any person in a company set-up has got a moral duty to report [irregularities]' (U2).

Despite the fact that the $\mathrm{RI}$ provisions may lead to otherwise administrative issues being reported (Wielligh, 2006; IRBA, 2006) this general sense of moral duty continues to hold:

We certainly see more Rls....and one reason is that people never used to see the reports if the client had corrected the issue whereas now, even if it has been corrected, there is still an obligation to report. And I don't think that that is bad. I think that people have a right to know what is going on and to make their own minds up' (U3).

In line with codes on corporate governance (see King-III, 2009; Solomon, 2010) whistle-blowing becomes inextricably part of the ethical culture of an organisation and type of moral imperative in the name of the transparency (U9; U6). Ultimately, by blowing the whistle, s45 of the APA becomes an act perceived to be in the public interest by virtually all users and experts (see also: Nel, 2001). For example, several users suggested that the legitimacy-potential of the reporting duty may be attributed to assessment of the benefits of prior whistle-blowing. Past scandals, whether in South Africa or abroad, were offered as examples of the future prospects of enhancing transparency for the greater social good (U2; U5; U13). 
Adding to this sense of whistle-blowing as the 'right thing to do' is procedural rigour, particularly the fact that the reporting duty is enshrined in statue. Suchman's (1995) argues that rational legal systems may confer a sense of authority and possibly general acceptance of an organisation (see also Meyer and Rowan, 1977; Molm, 1986; Goldhamer and Shils, 1939; Georgiou and Jack, 2011). These legal requirements effectively constitute rational, generally accepted methodologies or prescriptions resulting from due process that 'back' the respective policy (Suchman, 1995; Meyer and Rowan, 1977; Power, 2003). In other words, the procedures or techniques used to attain legitimacy ought to be legitimate in their own right (see also: Power, 2003), something especially important given the subjectivity inherent in 'clearly defining outcome measures' in the context of whistle-blowing (consider: Staub, 1978; Hwang et al, 2008; Miceli and Near, 1984; Suchman, 1995, p. 580). The RI provisions may, therefore, confer auditors with a measure of legitimacy not only by virtue of aligning audit with acts of whistle-blowing perceived as morally and socially appropriate (U2; U12). The statutory requirement to blow the whistle may partially confer legitimacy precisely because it has been formalised in statue (E1; E5; E15).

Users, for instance, reported that the fact that the reporting duty was a legal, rather than simply a professional one, enhanced its perceived utility. Whistle-blowing requirements were described as 'crystallised' (U1) and not subject the changing whims of the profession (E3; E7; E16) which almost all users felt reinforced notions of moral propitiatory. Similarly, the need to send formal reports to the IRBA, coupled with 'layers of independence' (E6) in terms of which final decisions to escalate reports rest with the regulator rather than the auditor, demonstrated 'procedural rigour' and 'objectivity' (E17; U7; U10; U11). As theorised by Suchman (1995), users reported that clearly defined legal protocols enhanced the perceived value of the reporting duty (influential and exchange legitimacy) as well as the conviction that, on average the reporting duty is consistent with various stakeholder interests.

For users, complementing the specific reporting procedures is the fact that the auditor is 'perfectly placed' to discharge those duties (U2). The technical expertise of the audit firm, coupled with its commitment to ethical standards and professional duty (E1; E2; E8; E9), reinforces the practical ability of the auditor to blow the whistle on the client when required by the legislation (E3; U2). In the absence of this practical ability, it would be doubtful that sustained consequential and pragmatic legitimacy could result. Just as Suchman (1995, p. 581), asks: does the manufacturing concern have a quality control department to support the claim to structural legitimacy, the fact that the auditor has the necessary resources at his disposal, including access to the client, has a similar effect. 
For instance, stakeholders

'can believe in the consequential effects of whistle-blowing, because it is conceivable that the auditor can comply with the reporting duty allowing the act of reporting transgressions to afford a sense of legitimacy' (U13).

Brand awareness, risk of litigation, a sense of professional commitment and internally held values and beliefs complement this. Per Palmrose (1988; 1997), Carrington (2010) and DeAngelo (1981a; $1981 b ; 1988)$, each 'element' forms an integral part of the audit quality framework and, in the context of structural legitimacy, reassures users of the practicality of the auditor's reporting duty and propensity for whistle-blowing. This is particularly important for securing trust in the 'black box' (Power, 1994) that is the audit process. User 1 and 3 explain:

So how do we know if the auditor finds a RI he really reports it and doesn't just ignore it? I don't think that that is very likely because of the very nature of auditing. The auditor would, in effect, be putting his personal position at risk...not only because of the financial consequences but the clear reputational and professional consequences as well. So the stakes are too high and this is not just about the money or possibly going to jail. The stakes are high because [the consequences of not reporting] are so personal and so inconsistent with the very nature of the audit firms' (U1). In other words, 'the ramifications are so severe...that I don't think we need to be worried [about the auditor]...sweeping [irregularities] under the carpet' (U3).

Experts have similar convictions:

'From a practical point of view, we are well placed. We have the integrity and the resources and the reporting duty ties in with what we do as part of an audit anyway' (E8) and 'at the end of the day, we have a professional and moral obligation to tackle irregularities appropriately as part of the professional standards, our commitment to the brand, and for yourself, as a professional accountant' (E5). 'You don't just study seven years and work your arse off to become a partner at a respectable audit firm to just forget about these duties' (E7).

In this way, procedural, structural and consequential legitimacy are interconnected (Suchman, 1995). That the South African auditor's duty to report is enshrined in law; that the auditor is practically capable of discharging the duty; that there are ramifications for not complying; and that users feel that the reporting requirement is the 'right thing to do' (U3), leads to the conclusion by most users that the $\mathrm{RI}$ provisions result in a socially desirable output. Per User 2 and Expert 1:

'while s45 of the APA does not change audit on the ground, it is definitely in the public interest. Whenever you bring in an additional requirement to report companies to keep them honest....that is certainly in the public interest; it is certainly the moral thing to do; and it is definitely an important means of conferring legitimacy on the audit profession' (User 2). 
'In a way, s45 of the APA gives users a sense of comfort and formalises a willingness by the profession to blow the whistle' (E1). 'It is a demonstrable commitment to meeting market expectations and the expectations of users that, when an irregularity is found, there is at least a formal process for brining this into the public domain' (E13). 'So, in conclusion, I think that it [complying with s45 of the APA] is the right thing to do and does offer the audit profession a sense of moral standing or legitimacy - definitely' (E8).

In essence, what the prior literature on whistle-blowing (Hwang et al, 2008; Reckers-Sauciuc and Lowe, 2010), the financial press (PwC, 2011b; KPMG, 2011; ICSA, 2011) and the comments of several respondents highlight is the conviction that whistle-blowing is pro-social in nature (Staub, 1978), morally and socially justifiable (U12; E16) and, ultimately, 'the right thing to do' (U2). The RI provisions may be an extension of this, capitalising on the moral 'acceptability' of whistle-blowing and expanding it into the auditor's domain. As argued by both Suchman (1995) and Meyer and Rowan (1977), laws and public opinion make it desirable for auditors to incorporate the whistleblowing duty, gaining moral legitimacy in the process.

What should also be noted is that the same outcome that is being perceived as morally legitimate was also, as discussed in Section 4.1, associated with being in the self-interest of different constituencies, and thus a source of pragmatic legitimacy. This is not a contradiction. In a complex social setting both forms of legitimacy often coexist (Suchman, 1995; O'Dwyer et al, 2011; Georgiou and Jack, 2011). A key difference, however, is that moral legitimacy does not depend on the perceived self-interest or utility of whistle-blowing but is rather a product of social and cultural evaluations' leading to a favourable, but still normative, view of whistle-blowing, under s45 of the APA (see, for example, Suchman, 1995).

\section{3: On the road to cognitive legitimacy}

Virtually all respondents accepted the act of reporting transgressions as a natural part of the South African corporate governance landscape. Analogously, the financial press points to the 'taken-forgranted' or automatically accepted need for whistle-blowing as a means for enhancing transparency and combating corruption (see, for example, PwC, 2011b; PwC, 2011a; Crotty, 2007; Mboyisa, 2009; Vecchiatto, 2011). While blowing the whistle on a client under the RI provisions may not be the primary objective of an audit (IRBA, 2006; PwC, 2006), the reporting duty may be placed at the intersection between the taken-for-granted acceptance of both the existence of audit and whistleblowing in general allowing each to re-enforce the other. As argued by Suchman $(1995$, p. 582) if the 
role of an organisation can be 'meshed' with a larger belief system or accepted reality of an audiences daily life, legitimacy rooted in comprehensibility may result.

This view also implies that daily experiences can be used by analogy to afford support to a given function. Interestingly, and as discussed above, several respondents likened audit and the RI provisions with a 'watchdog'. The act of blowing the whistle on a client's transgressions was perceived as a mechanism for sounding the alarm, brining more into the open than the traditional audit report and was cited as a possible source of pragmatic and moral legitimacy. The analogy between audit and the 'watchdog', however, reinforces notions of growing cognitive legitimacy.

A comparable outcome was achieved by Robert Noyce, founder of Intel, who was able to draw analogies between paper clips - a common office consumable - and the utility of then theorised microprocessor which would have enormous potential despite its small size (Rogers and Larsen, 1984 cited in Suchman, 1995, p. 582). From the perspective of external audit, the auditor was originally able to garner public trust by drawing parallels between the practitioner and the Victorian ideals of the 'gentleman' who was above working for a wage and acted appropriately, (McMillan, 2004; Edwards, 2001). When it then comes to auditors reporting under s45 of the APA, the duty is juxtaposed with a 'watchdog', a readily comprehensible part of daily life, and with whistle-blowing which is increasingly accepted as 'natural' part of the corporate governance machinery (see PwC, 2009a; PwC, 2009b; PwC, 2011b; Solomon, 2009; Solomon, 2010; King-III, 2009). In other words, a sense of innate comprehensibility complements the mutual reinforcing 'taken-for-granted-ness' of audit and whistle-blowing (see also: Suchman, 1995; Llewelyn, 2003). This viewpoint is captured by the response of Expert 17 when invited to participate in the research:

'why do you want to talk about s45 of the APA and whistle-blowing? Surely that stuff is obvious? The auditor has the duty to report Rls to the IRBA - its part and parcel of what the auditor does. It's both a logical and inevitable part of corporate governance in South Africa. Whistle-blowing is to corporate governance what debits and credits are to accountancy' (E17).

A less abstract view of cognitive legitimacy comes from the institutionalists who argue that 'comprehensibility' and 'taken for grantedness' can be achieved through mimetic isomorphism (DiMaggio and Powell, 1983; Meyer and Rowan, 1977; Fogarty, 1992; Rodrigues and Craig, 2007). In this context, requiring the auditor to blow the whistle on client transgressions conforms with growing international trends championing reporting to third parties (U4; U8; Epps and Guthrie, 2010; Nel, 2001; PwC, 2011b). For example, France, Malaysia, the USA and UK have legislation that addresses whistle-blowing (Nel, 2001; Brennan and Kelly, 2007; Riotto, 2008) while the European Community is currently exploring the possibility of broadening the scope of the auditor's reporting duty and currently requires auditors to report certain transgressions, mainly in a financial services 
setting (European Commission, 2010; European Commission, 2010a; CESR, 2007). In addition, that the auditor's reporting duty is enshrined in statue signals a move towards a more arms-length approach to auditor regulation ( $\mathrm{Nel}, 2001)$ that may also be part of securing legitimacy through a process of mimetic isomorphism.

As discussed in Section 2, corporate scandals have shaken the confidence vested in the audit profession and its self-regulatory systems. Compliance with the RI provisions by audit firms may be part of the process of conforming to societal ideals or norms which, increasingly, appear to favour external regulation over the traditional self-regulatory approach (see, for example, Konar et al, 2003; Nel, 2001; Bazerman and Moore, 2011; Sy and Tinker, 2008). For example, Expert 3 , discussing the use of more arms-length regulation for the audit profession, felt that:

'we need to strike a balance between self regulation and legal requirements. You can't cater for everyone but I don't think that it would have been wise to just continue the way we were with regulations coming only from within the profession' (E3).

Similarly, Expert 7 maintained that:

'with the increased fraud, and Enron and everything else that was happening, it was necessary to change. To an extent, this was a response to changes overseas but it was also about addressing shareholders' concerns and reassuring them that when [RIs are detected] they get reported' (E7).

In this light, the 'whole Enron-SOX mess definitely had ripple effects for South Africa' (U1) with the result that it would have been 'unwise' (U4) for the South African government to fail to consider regulatory developments abroad for fear of being perceived as ineffective and ill-responsive (U1; U4). This is not because the $\mathrm{Rl}$ provisions resulted in a paradigm shift in the way audits are executed (E5; E8) but because they signal a reaction to emerging challenges from abroad that may have begun to undermine the effectiveness of the self-regulatory ethos as the traditional source of auditor legitimacy (see also: Edwards, 2001; Zeff, 2003a; Mosso, 2003). Based on DiMaggio and Powell's (1983) model of mimetic isomorphism, replicating, at least in part, the move to more armslength regulation taking hold in developed economies (see: European Commission, 2010; European Commission, 2010a; Bazerman and Moore, 2011; Canada et al, 2008; Unerman and O'Dwyer, 2004), becomes a powerful means of securing the legitimacy of the South African audit profession.

As summarised by Konar et al (2003, p. 28), when it comes to the legitimacy of the South African capital market system, including the audit process, 'it is important that South Africa be seen to be in step with international developments regarding corporate governance'(Konar et al, 2003, p. 28). Through achieving a sense of parity with developments in other jurisdictions, s45 of the APA 
appears to conjure up confidence rooted in the fact that South Africa has not simply maintained a self-regulatory status quo while, internationally, external regulation is championed (for examples see: Bazerman and Moore, 2011; Gavious, 2007; Sy and Tinker, 2008; Konar et al, 2003). As a result, almost all users pointed to the fact that formalising the duty to blow the whistle when Mls were replaced with Rls; broadening the reporting duties; clarifying that the RI provisions are under official control of an independent regulator; and reminding constituents of the existence of this legal duty capitalises on a sense of mimetic isomorphism that fortifies the sense of comprehensibility and generally accepted 'correctness' of the auditor's duties (U7).

Complementing this is the fact that $\mathrm{RI}$ provisions have been indirectly endorsed by external assessment criteria. User 2 and Expert 8 and 9, for example, defended the 'appropriateness' and 'plausibility' of the reporting duty on the grounds that South Africa's audit and accounting practices have been independently ranked first on the international stage (IRBA, 2010). These 'ceremonial' tokens of worth enhance the compressibility of an act or organisation and reinforce their presumed appropriateness. They confirm that the act in question is based on the latest thinking or is a revered 'first of its kind, adding to perceived credibility (Meyer and Rowan, 1977, pp. 350-351).

At first blush, this argument appears abstract. Isomorphism, formalisation of the whistle-blowing process and its control by an independent regulator are relatively subtle means of achieving legitimacy for the audit profession. Unlike a direct link between audit and utility for constituents or between audit and the morally (and normative) sound action of blowing the whistle the preceding techniques appeal more to a sense of common knowledge, taken for granted 'truths' and the belief in formalised processes (consider: Suchman, 1995; Meyer and Rowan, 1977; Power, 1994; Humphrey and Moizer, 1990; Pentland, 2000). Paradoxically, the very power of cognitive legitimacy is that it is rooted in the abstract (Suchman, 1995, p. 596) 


\section{5: Conclusion}

This paper has examined South Africa's RI provisions as an example of regulation aimed directly at the audit profession, from an institutional perspective. Unlike prior studies that have made inferences about the relationship between audit practice, quality and regulation based on quantitative analysis of archival data or 'surrogates', detailed interviews are used to shed light on how external regulation contributes to the legitimacy of audit practice in a real-world setting.

The research has argued that perceived gains in transparency and conceptions of a whistleblowing duty being in the public interest are important sources of pragmatic and moral legitimacy. This is complemented by the fact that auditors are privy to the inner workings of their client, in possession of the necessary technical and professional skills, and subject to a formal reporting requirement that defines when and how to blow the whistle.

Concurrently, the $\mathrm{Rl}$ provisions mark an increasing move away from the self-regulatory paradigm which, in the aftermath of numerous corporate scandals, may be suffering from an impaired legitimisation potential. Requiring the auditor to report transgressions signals a move towards more external regulation as a means of preserving trust in the audit process. More specifically, the RI provisions may be part of the response to regulatory developments abroad. With South Africa's major trade partners and providers of capital appearing to favour external regulation (Konar et al, 2003; Manuel, 2002), s45 of the APA serves as an example of isomorphism aimed at ensuring legitimacy.

These results ultimately confirm the findings of Power (2003; 1994) - that audit is a social construct and that, paradoxically, is both able to confer legitimacy on organisations yet, depends heavily on legitimacy in its own right in order to do so. Accordingly, external regulation is not only about improving audit quality, as much of the prior literature suggests. By appealing to notions of pragmatic, moral and cognitive legitimacy it is an important means of securing belief in the auditors' 'rituals' of verification (Pentland, 2000), something particularly important given that the only 'element' of audit capable of direct observation is a single sheet of paper expressing an opinion on a set of financial statements. 
In reaching this conclusion, it is important to note that this research is not without limitations. A single case study focusing on a particular point in time is used to illuminate the relationship between external regulation and processes of legitimisation. Additional research testing the application of legitimacy theory in this manner, but in other jurisdictions is, therefore, needed. In addition, the paper lacks a critical bite and assumes that claims to legitimacy are bona fide. Suchman (1995, p. 579), however, warns that 'organisations often put forth self-serving claims of moral proprietary and buttress these claims with hollow symbolic gestures'. Similarly, Power (1994) and Unerman and O'Dwyer (2004) argue that seldom are regulatory developments untainted by various agendas. For example: governments, having a vested interest in the functioning of capital markets, and thus external audit, may use external regulation a means to superficially legitimise audit. As a result, future research may adopt a more critical stance enquiring if South Africa's RI provisions - and other auditor regulation, like SOX - are part of a symbolic or ceremonial process used simply to perpetuate belief in the audit function while difficulties facing the profession are decoupled from the illusion of active reform improving audit quality and credibility of capital markets.

\section{Appendix 1: List of Respondents}

\begin{tabular}{|l|l|l|}
\hline$\#$ & Type & Job title or description ${ }^{\text {vii }}$ \\
\hline 1 & Expert 1 & Audit Partner \\
\hline 2 & Expert 2 & Audit Partner \\
\hline 3 & Expert 3 & Audit Partner \\
\hline 4 & Expert 4 & Audit Partner \\
\hline 5 & Expert 5 & Audit Partner \\
\hline 6 & Expert 6 & Audit Partner \\
\hline 7 & Expert 7 & Audit Partner \\
\hline 8 & Expert 8 & Audit Partner \\
\hline 9 & Expert 9 & Audit Partner \\
\hline 10 & Expert 10 & Audit Partner \\
\hline 11 & Expert 11 & Audit Partner \\
\hline 12 & Expert 12 & Audit Partner \\
\hline 13 & Expert 13 & Audit Partner \\
\hline 14 & Expert 14 & Audit Partner \\
\hline 15 & Expert 15 & Audit Partner \\
\hline 16 & Expert 16 (R101) & $\begin{array}{l}\text { Audit standards, compliance, internal reviewer or external } \\
\text { reviewer }\end{array}$ \\
\hline 17 & Expert 17 (R101) & $\begin{array}{l}\text { Audit standards, compliance, internal reviewer or external } \\
\text { reviewer }\end{array}$ \\
\hline 18 & User 1 & $\begin{array}{l}\text { Audit standards, compliance, internal reviewer or external } \\
\text { reviewer }\end{array}$ \\
\hline 19 & User 2 & Audit committee member \\
\hline
\end{tabular}




\begin{tabular}{|l|l|l|}
\hline 20 & User 3 & $\begin{array}{l}\text { Audit standards, compliance, internal reviewer or external } \\
\text { reviewer }\end{array}$ \\
\hline 21 & User 4 & Audit committee Member/Investor \\
\hline 22 & User 5 & Audit Committee Member \\
\hline 23 & User 6 & $\begin{array}{l}\text { Audit standards, compliance, internal reviewer or external } \\
\text { reviewer }\end{array}$ \\
\hline 24 & User 7 & $\begin{array}{l}\text { Audit standards, compliance, internal reviewer or external } \\
\text { reviewer }\end{array}$ \\
\hline 25 & User 8 & Audit Committee Member \\
\hline 26 & User 9 & Institutional investor \\
\hline 27 & User 10 & Institutional Investor \\
\hline 28 & User 11 & Institutional Investor \\
\hline 29 & User 12 & $\begin{array}{l}\text { Audit standards, compliance, internal reviewer or external } \\
\text { reviewer }\end{array}$ \\
\hline 30 & User 13 (R101) & $\begin{array}{l}\text { Audit standards, compliance, internal reviewer or external } \\
\text { reviewer }\end{array}$ \\
\hline
\end{tabular}

\section{Notes}

'Non standard abbreviations include: the Auditing Profession Act No. 26 of 2005 (APA); Public Accountants' and Auditors' Board (PAAB); Independent Regulatory Board for Auditors (IRBA), International Auditing and Assurance Standards Board (IAASB); International Financial Reporting Standards (IFRS); International Standards on Auditing (ISA); Reportable Irregularities (RI); South African Institute of Chartered Accountants (SAICA)

ii There is a considerable body of work examining the effect of arms-length regulation on audit practice. This research, however, tends to rely on inferential testing often based on audit quality surrogates to reach conclusions on the effects of regulations, like SOX, on audit practice. For example, examining the effect of PCAOB inspections, Carcello et al (2011) consider changes in firms' abnormal accrual balances while DeFond and Lennox (2011) examine how these quality inspections impact the propensity to modify audit reports on the basis of concerns about the going concern assumption. Similarly, Vakkur et al (2010) and Bronson et al (2011) rely on archival data to argue that SOX may have had unintended consequences.

iii The objective on an audit, according to the IAASB (2009a: 3), is to obtain 'reasonable assurance about whether [an audit client's] financial statements, as a whole, are free from material misstatement, whether due to fraud or error, thereby enabling the auditor to express an opinion on whether the financial statements are prepared, in all material respects, in accordance with the applicable financial reporting framework and to report on the financial statements, and communicate as required by [International Standards on Auditing] ISAs in accordance with the auditor's findings'. 
iv For example, suspicion has been raised that the 'independence', 'integrity', 'professional competency' and 'due care' amount to a 'professional mystique' that is used to further the economic interests of members of the profession with little regard for the public interest (for examples, see Cagnin et al, 2011; Pesqueux, 2005, Humphrey et al, 1992). This line of thought, while interesting, is deferred for subsequent research to allow this paper to make an initial clear case for the relevance of legitimacy theory in a practical audit setting.

v There are several definitions of whistle-blowing. Near and Miceli (1984, p. 824) define 'whistle blowing' as: 'the disclosure by 'organization members... of illegal, immoral or illegitimate practices under the control of the employer to persons or organizations who may be able to effect action'. Jubb (1999), Staub (1978) and Hwang et al. (2008) adopt a similar definition, stressing the importance of acting for the greater good, rather than primarily for self-interest. Although Near and Miceli $(1984 ; 1995)$ refer specifically to divulgences in an employer-employee context, the substance of reporting under the APA or in a traditional master-servant relationship is similar. With $s 45$ of the APA, there is a sense of serving the public interest (or greater good) (Nel, 2001; van Esch et al, 2004). The auditor is entitled to no direct material benefit for reporting (IRBA, 2006) implying the absence of self-gain. Reporting by the auditor also involves the challenging of perceived authority - in this case the need to preserve the client relationship (consider: Windsor and Ashkanasy, 1995; Farag and Elias, 2011). Accordingly, Rotter (1966) maintains that even obligatory acts of reporting may be defined as 'whistle-blowing'. What is perhaps more important for the purpose of this research is not whether $\$ 45$ of the APA fits neatly into a formal definition of 'whistle-blowing' but rather the connotations resulting from several respondents highlighting the reporting duty as an act of blowing the whistle.

${ }^{\text {vi }}$ It must be stressed that $\mathrm{s} 45$ of the APA would likely require an auditor to report an act of fraud to the IRBA if the fraud involved the client's 'management board' (IRBA, 2006). The reporting duty is not, however, only concerned with fraud. Acts of or omissions on the part of a client's management board which result in material financial loss or constitute material breaches of fiduciary duties could also be reportable (IRBA, 2006; PwC, 2006). What the APA does not, however, do is establish a duty for the auditor to detect fraud. The auditor would simply be obliged to report a fraud (meeting the definition of a 'reportable irregularity' per s1 of the APA) which comes to his attention during the course of carrying out audit procedures in compliance with ISA. Several papers have identified this as contributing an 'expectation gap' (for examples: Humphrey et al, 1992; Khalifa et al, 2007b; Humphrey, 2008). This research is, however, concerned with the RI provisions as a source of legitimacy. Whether or not they contributes to resolving or aggravates the expectation gap with respect to an auditor's fraud-detection duties is not specifically within the scope of this research.

vii Job titles and descriptions have been altered to preserve the identity of respondents. 


\section{References}

Abbott, A. 1981. Status and Status Strain in the Professions. American Journal of Sociology, 86, 819-835.

Ahrens, T., Becker, A., Burns, J., Chapman, C. S., Granlund, M., Habersam, M., Hansen, A., Khalifa, R., Malmi, T., Mennicken, A., Mikes, A., Panozzo, F., Piber, M., Quattrone, P. \& Scheytt, T. 2008. The future of interpretive accounting research--A polyphonic debate. Critical Perspectives on Accounting, 19, 840-866.

Alvesson, M. 2003. Beyond Neopositivists, Romantics, and Localists: A Reflexive Approach to Interviews in Organizational Research. The Academy of Management Review, 28, 13-33.

APA 2005. Auditing Profession Act No. 26 of 2005. Republic of South Africa.

Ashforth, B. E. \& Gibbs, B. W. 1990. THE DOUBLE-EDGE OF ORGANIZATIONAL LEGITIMATION. Organization Science, 1, 177-194.

Ashton, R. H. 1992. Effects of justification and a mechanical aid on judgment performance. Organizational Behavior and Human Decision Processes, 52, 292-306.

Baker, R. C. \& Owsen, D. M. 2002. Increasing the role of auditing in corporate governance. Critical Perspectives on Accounting, 13, 783-795.

Baldvinsdottir, G., Burns, J., Nørreklit, H. \& Scapens, R. 2009. The image of accountants: from bean counters to extreme accountants. Accounting, Auditing and Accountability Journal, Vol. 22, 858882.

Barth, M. E. 2008. Global Financial Reporting: Implications for U.S. Academics. The Accounting Review, 83, 1159-1179.

Bayou, M. E., Reinstein, A. \& Williams, P. F. 2011. To tell the truth: A discussion of issues concerning truth and ethics in accounting. Accounting, Organizations and Society, 36, 109-124.

Bazerman, M. H. \& Moore, D. 2011. Is it time for auditor independence yet? Accounting, Organizations and Society, 36, 310-312.

Brennan, N. \& Kelly, J. 2007. A study of whistleblowing among trainee auditors. The British Accounting Review, 39, 61-87.

Brennan, N., M. \& Solomon, J. 2008. Corporate governance, accountability and mechanisms of accountability: an overview. Accounting, Auditing \& Accountability Journal, 21, 885-906.

Bronson, S. N., Hogan, C. E., Johnson, M. F. \& Ramesh, K. 2011. The unintended consequences of PCAOB auditing Standard Nos. 2 and 3 on the reliability of preliminary earnings releases. Journal of Accounting and Economics, 51, 95-114.

Burchell, S., Clubb, C., Hopwood, A., Hughes, J. \& Nahapiet, J. 1980. The roles of accounting in organizations and society. Accounting, Organizations and Society, 5, 5-27.

Byington, J. R. \& Sutton, S. G. 1991. The self-regulating profession: An analysis of the political monopoly tendencies of the audit profession. Critical Perspectives on Accounting, 2, 315-330.

Cagnin, C., Loveridge, D. \& Saritas, O. 2011. FTA and equity: New approaches to governance. Futures, 43, 279-291.

Canada, J., Kuhn, J. R. \& Sutton, S. G. 2008. Accidentally in the public interest: The perfect storm that yielded the Sarbanes-Oxley act. Critical Perspectives on Accounting, 19, 987-1003.

Carcello, J. V., Hollingsworth, C. \& Mastrolia, S. A. 2011. The effect of PCAOB inspections on Big 4 audit quality. Research in Accounting Regulation, 23, 85-96.

Carrington, T. 2010. An analysis of the demands on a sufficient audit: Professional appearance is what counts! Critical Perspectives on Accounting, 21, 669-682.

Carruthers, B. G. 1995. Accounting, ambiguity, and the new institutionalism. Accounting, Organizations and Society, 20, 313-328. 
CESR 2007. Survey on the Direct Communication of Audiotors with the Public on the Stautory Audit of the Annual or Consolidated Accounts of Listed Companies. Paris: Committee of European Securities Regulators

Chandler, R., Edwards, R. \& Anderson, M. 1993. Changing Perceptions of the Role of the Company Auditor, 1840-1940. Accounting and Business Research, Vol. 23, 443-459.

Church, B. K. \& Shefchik, L. B. 2011. PCAOB Inspections and Large Accounting Firms. Accounting Horizons, 26, 43-63.

Companies Act 2008. Companies Act No. 71 of 2008. Republic of South Africa.

Cooper, D. J. \& Robson, K. 2006. Accounting, professions and regulation: Locating the sites of professionalization. Accounting, Organizations and Society, 31, 415-444.

Cowton, C. J. \& Dopson, S. 2002. Foucault's prison? Management control in an automotive distributor. Management Accounting Research, 13, 191-213.

Creswell, J. 2009. Research Design: Qualitative, Quantitative, and Mixed Methods Approaches, Third Edition, Sage Publications, London.

Crotty, A. 2007. Tiger-Brands price fixing scandal a drop in the ocean. Business Report.

Cullinan, C. P., Du, H. \& Zheng, X. 2012. Barriers to entry to the big firm audit market: Evidence from market reaction to switches to second Tier audit firms in the post-sox period. Research in Accounting Regulation, 24, 6-14.

Dart, E. 2011. UK investors' perceptions of auditor independence. The British Accounting Review, 43, 173-185.

DeAngelo, L. E. 1981a. Auditor independence, 'low balling', and disclosure regulation. Journal of Accounting and Economics, 3, 113-127.

DeAngelo, L. E. 1981b. Auditor size and audit quality. Journal of Accounting and Economics, 3, 183-199.

DeAngelo, L. E. 1988. Managerial competition, information costs, and corporate governance : The use of accounting performance measures in proxy contests. Journal of Accounting and Economics, 10, 3-36.

DeFond, M. L. \& Lennox, C. S. 2011. The effect of SOX on small auditor exits and audit quality. Journal of Accounting and Economics, 52, 21-40.

Deloitte. 2010. Response to European Commission Green Paper on "Audit Policy: Lessons from the Crisis". Available: http://ec.europa.eu/internal_market/consultations/2010/green_paper_audit_en.html.

DiMaggio, P. \& Powell, W. 1983. The Iron Cage Revisited: Institutional Isomorphism and Collective Rationality in Organizational Fields. American Sociology Review, 48, 147-160.

Dunn, T., Jooste, R. \& Smith, P. 1989. Material Irregularities and the Auditor's Report. South African Journal of Accounting Research, 3, 9-17.

Edwards, J. R. 2001. Accounting regulation and the professionalization process: an historical essay concerning the significance of P. H. Abbott. Critical Perspectives on Accounting, 12, 675-696.

Epps, R. W. \& Guthrie, C. P. 2010. Sarbanes-Oxley 404 material weaknesses and discretionary accruals. Accounting Forum, 34, 67-75.

European Commission. 2010. GREEN PAPER Audit Policy: Lessons from the Crisis. Available: http://europa.eu/rapid/pressReleasesAction.do?reference=MEMO/10/487\&format=HTML\&aged= 0\&language $=E N \&$ guiLanguage $=e n$ [Accessed 2 April 2011].

European Commission. 2010a. Green Paper on Audit Policy-frequently asked questions. Available: http://europa.eu/rapid/pressReleasesAction.do?reference=MEMO/10/487\&format=HTML\&aged= 0\&language $=E N \&$ guil Language $=e n$.

Farag, M. \& Elias, R. 2011. Relative audit fees and client loyalty in the audit market. Accounting Research Journal, 24, 79-93.

Fligstein, N. \& Feeland, R. 1995. Theoretical and Comparative Perspectives on Corporate Organization. Annual Review of Sociology, 21, 21-43.

Fogarty, T. J. 1992. Organizational socialization in accounting firms: A theoretical framework and agenda for future research. Accounting, Organizations and Society, 17, 129-149. 
Fogarty, T. J., Helan, J. B. \& Knutson, D. L. 1991. The rationality of doing "nothing": Auditors' responses to legal liability in an institutionalized environment. Critical Perspectives on Accounting, 2, 201226.

Francis, J. R., Reichelt, K. \& Wang, D. 2005. The Pricing of National and City-Specific Reputations for Industry Expertise in the U.S. Audit Market. Accounting Review, 80, 113-136.

FRC. 2008. The Audit Quality Framework. Available: http://www.frc.org.uk/images/uploaded/documents/Audit\%20Quality\%20Framework\%20for\%20w eb1.pdf.

FRC. 2010. Audit Inspection Unit 2009/10 Annual Report. Available: http://www.frc.org.uk/images/uploaded/documents/AIU\%20Annual\%20Report\%20200910\%20Final.pdf.

FRC. 2011. FRC acts to increase transparency in corporate reporting [Online]. London: Financial Reporting Council (FRC). Available: http://www.frc.org.uk/press/pub2632.html [Accessed 1 September 2011].

Fuerman, R. D. 2004. Accountable accountants. Critical Perspectives on Accounting, 15, 911-926.

Gavious, I. 2007. Alternative perspectives to deal with auditors' agency problem. Critical Perspectives on Accounting, 18, 451-467.

Gawith, K. 2006. Reportable Irregularities [Online]. Available: www.deneysreitz.co.za/index.php/news/reportable_irregularities/ [Accessed 7 February 2011].

Georgiou, O. \& Jack, L. 2011. In pursuit of legitimacy: A history behind fair value accounting. The British Accounting Review, 43, 311-323.

Gold, A., Gronewold, U. \& Pott, C. 2012. The ISA 700 Auditor's Report and the Audit Expectation Gap Do Explanations Matter? International Journal of Auditing, no-no.

Goldhamer, H. \& Shils, E. A. 1939. Types of Power and Status. American Journal of Sociology, 45, 171182.

Hill, C. W. L. \& Jones, T. M. 1992. STAKEHOLDER-AGENCY THEORY. Journal of Management Studies, 29, $131-154$.

Holland, J. 1998a. Private Disclosure and Financial Reporting. Accounting and Business Research, 28, 255-269.

Holland, J. 1998b. Private Voluntary Disclosure, Financial Intermediation and Market Efficiency. Journal of Business Finance \& Accounting, 25, 29-68.

Hopper, T. \& Macintosh, N. 1993. Management accounting as disciplinary practice: the case of ITT under Harold Geneen. Management Accounting Research, 4, 181-216.

Hopwood, A. G. 1987. The archeology of accounting systems. Accounting, Organizations and Society, 12, 207-234.

Humphrey, C. 2008. Auditing research: a review across the disciplinary divide. Accounting, Auditing \& Accountability Journal, 21, 170-203.

Humphrey, C. \& Moizer, P. 1990. From techniques to ideologies: An alternative perspective on the audit function. Critical Perspectives on Accounting, 1, 217-238.

Humphrey, C., Moizer, P. \& Turley, S. 1992. The audit expectations gap--plus ca change, plus c'est la meme chose? Critical Perspectives on Accounting, 3, 137-161.

Hwang, D., Staley, B., Chen, Y. \& Lan, J. 2008. Confusion culture and whistle-blowing by professional accountants: an exploratory study. Managerial Auditing Journal, 23, 504-526.

IAASB 2009a. ISA 200: Objective and General Principles Governing an Audit of Financial Statements. In: SOUTH AFRICAN INSTITUTE OF CHARTERED ACCOUNTANTS (ed.) SAICA Members' Handbook. 2009 ed. Pietermaritsburg: LexisNexis.

IAASB 2009b. ISA 700: Forming an opinion and reporting on financial statements $I n$ : SOUTH AFRICAN INSTITUTE OF CHARTERED ACCOUNTANTS (ed.) SAICA Members' Handbook. 2009 ed. Pietermaritsburg: LexisNexis.

IAASB 2009c. ISQC1: Quality Control for Firms That Perform Audits and Reviews of Historical Financial Information, and Other Assurance and Related Services Engagements. In: SOUTH AFRICAN 
INSTITUTE OF CHARTERED ACCOUNTANTS (ed.) SAICA Members' Handbook.

Pietermaritsburg: LexisNexis.

IAASB 2009d. PREF1: Preface to the International Standards on Quality Control, Auditing, Review, Other Assurance and Related Services. In: SOUTH AFRICAN INSTITUTE OF CHARTERED ACCOUNTANTS (ed.) SAICA Members' Handbook. 2009 ed. Pietermaritsburg: LexisNexis.

IAASB. 2012. Improving the Auditor's Report: Invitation to Comment. Exposure Drafts and Consultation Papers [Online]. Available:

http://www.ifac.org/sites/default/files/publications/files/Auditor_Reporting_Invitation_to_Commentfinal_0.pdf [Accessed 8 July 2012].

IASB 2009. Framework for the Preparation and Presentation of Financial Statements, Pitermartisburg, LexisNexus (International Accounting Standards Committee Foundation Publications Department).

ICSA. 2011. The NHS Constitution and Whistleblowing [Online]. Available: http://www.icsa.org.uk/assets/files/pdfs/guidance/Consultations\%202011/ICSA\%20Response\%20 Whistleblowing\%20and\%20NHS\%20Constitution.pdf [Accessed 19 August 2011].

IFAC 2006. Code of Professional Conduct, South African Institute of Chartered Accountants Members' Handbook, Pietermaritsburg, LexisNexis.

IRBA. 2006. Reportable Irregularities: a Guide Registered Auditors. Available: http://www.irba.co.za/index.php/component/docman/cat_view/19-compliance.

IRBA. 2010. South Africa ranked first out of 139 countries for its Strength of Auditing and Reporting Standards. Available: http://www.irba.co.za/index.php/audit-news-news-42/524-3-nov-2010.

IRC. 2011. Framework for Integrated Reporting and the Integrated Report. Available: www.sustainabilitysa.org.

Jensen, M. C. \& Meckling, W. H. 1976. Theory of the firm: Managerial behavior, agency costs and ownership structure. Journal of Financial Economics, 3, 305-360.

Jubb, P. B. 1999. Whistleblowing: A Restrictive Definition and Interpretation. Journal of Business Ethics, $21,77-94$.

Kaplan, S. E. \& Williams, D. D. 2012. The changing relationship between audit firm size and going concern reporting. Accounting, Organizations and Society, 37, 322-341.

Khalifa, R., Sharma, N., Humphrey, C. \& Robson, K. 2007. Discourse and Audit Change: transformations in methodology in the professional audit field. Accounting, Auditing and Accountability Journal, 20, 825-854.

King-III 2009. King III (2009), The King Code of Governance for South Africa (2009) and King Report on Governance for South Africa (2009), Lexis Nexus South Africa, Johannesburg, South Africa.

Konar, L., Levitt, S., Wainer, H. E., Anderson, S. J., Barrow, R. J. G., Burdett, S., Dwinger, H. P., Garach, D., Malan, C. C., Mtoba, F., Naidoo, V., Petros, M., Pretorius, W., Ramano, T. M., Sehoole, I., Williams, G. \& Wimberley, T. I. 2003. MINISTERIAL PANEL FOR THE REVIEW OF THE DRAFT ACCOUNTANCY PROFESSION BILL: REPORT TO THE MINISTER OF FINANCE. Johannesburg: Ministry of Finance: Republic of South Africa.

KPMG. 2010. European Commission Green Paper - Audit Policy: Lessons from the Crisis. Available: <http://ec.europa.eu/internal_market/consultations/2010/green_paper_audit_en.htm>.

KPMG. 2011. Ethics Line. Available: http://www.kpmg.com/ZA/en/lssuesAndlnsights/ArticlesPublications/RiskCompliance/Documents/Forensic\%20Ethics\%20Line.pdf [Accessed 26 November 2011].

Laughlin, R. 2007. Critical reflections on research approaches, accounting regulation and the regulation of accounting. The British Accounting Review, 39, 271-289.

Leedy, P. D. \& Ormrod, J. E. 2001. Practical Research: Planning and Design, New Jersey, Prentice Hall.

Lesage, C. \& Wechtler, H. 2012. An Inductive Typology of Auditing Research*. Contemporary Accounting Research, 29, 487-504.

Llewelyn, S. 1996. Theories for theorists or theories for practice? Liberating academic accounting research? . Accounting, Auditing \& Accountability Journal, 9, 112-117. 
Llewelyn, S. 2003. What counts as "theory" om qualitative management and accounting research? . Accounting, Auditing \& Accountability Journal, 16, 662-708.

Low, M., Davey, H. \& Hooper, K. 2008. Accounting scandals, ethical dilemmas and educational challenges. Critical Perspectives on Accounting, 19, 222-254.

MacLullich, K. K. 2003. THE EMPEROR'S 'NEW' CLOTHES? NEW AUDIT REGIMES: INSIGHTS FROM FOUCAULT'S TECHNOLOGIES OF THE SELF. Critical Perspectives on Accounting, 14, 791811.

Malsch, B. \& Gendron, Y. 2011. Reining in auditors: On the dynamics of power surrounding an "innovation" in the regulatory space. Accounting, Organizations and Society, 36, 456-476.

Manuel, T. 2002. BUDGET SPEECH BY THE MINISTER OF FINANCE [Online]. Republic of South Africa: Ministry of Finance. Available: http://www.info.gov.za/speeches/2002/020220246p1001.htm [Accessed 20 March 2012].

Marnet, O. 2007. History repeats itself: The failure of rational choice models in corporate governance. Critical Perspectives on Accounting, 18, 191-210.

Maroun, W. 2012. SOX-A Comparison With the South African Status Quo. Journal of Modern Accounting and Auditing, 8, 357-365.

Maroun, W. \& Segal, M. 2011. Sarbanes Oxley in South Africa - First World Meets Deep Dark Africa. Critical Perspectives on Accounting Conference. Florida, United States of America.

Mboyisa, C. 2009. Presidential Hot-Line Rings off the Hook. The Citizen.

McMillan, K. P. 2004. Trust and the virtues: a solution to the accounting scandals? Critical Perspectives on Accounting, 15, 943-953.

Meyer, J. W. \& Rowan, B. 1977. Institutionalized Organizations: Formal Structure as Myth and Ceremony. American Journal of Sociology, 83, 340-363.

Miceli, M. P. \& Near, J. P. 1984. The Relationships among Beliefs, Organizational Position, and WhistleBlowing Status: A Discriminant Analysis. The Academy of Management Journal, 27, 687-705.

Miller, P. \& O'Leary, T. 1987. Accounting and the construction of the governable person. Accounting, Organizations and Society, 12, 235-265.

Molm, L. D. 1986. Gender, Power, and Legitimation: A Test of Three Theories. American Journal of Sociology, 91, 1356-1386.

Mosso, D. 2003. A LONG FALL FROM GRACE. Research in Accounting Regulation, 16, 259-264.

Nam, D. \& Lemak, D. 2007. The whistle-blowing zone: applying Bernard's insights to a modern ethical dilemma. The Journal of Management History, 13, 33-42.

Near, J. P. \& Miceli, M. P. 1995. Effective Whistle-Blowing. The Academy of Management Review, 20 , 679-708.

Negash, M. 2004. Audit Hazard and Legal Regimes: Analysis of the Reform Issues in South Africa. Johannesburg: University of the Witwatersrand.

Negash, M., Abdol-Samad, T., Rabin, E., Lerman, J., Oosthuizen, A., Oosthuizen, T., Singh, D., Swartz, N., Padia, N., Patron, S., Gibbon, C. \& Hassan, Y. 2003. Final Research Report to the Ministerial Panel for the Review of the Draft Accountancy Profession Bill and National Treasury Johannesburg, South Africa: University of the Witwatersrand, School of Accountancy

Nel, H. C. 2001. Commission of enquiry into the affairs of the Masterbond Group and investor protection in South Africa.

O'Dwyer, B., Owen, D. \& Unerman, J. 2011. Seeking legitimacy for new assurance forms: The case of assurance on sustainability reporting. Accounting, Organizations and Society, 36, 31-52.

Oakes, L., Townley, B. \& Cooper, D. 1998. Business planning as pedagogy: language and control in a changing institutional field. Administrative Science Quarterly, 43, 257-293.

Odendaal, E. \& De Jager, H. 2008. Regulation of the Auditing Profession in South Africa. The Southern African Journal of Accountability and Auditing Research, 8, 1-13.

Owhoso, V. \& Weickgenannt, A. 2009. Auditors' self-perceived abilities in conducting domain audits. Critical Perspectives on Accounting, 20, 3-21.

PAAA 1951. Public Accountants' and Auditors' Act No. 80 of 1951. PAAA. Republic of South Africa.

PAAB 2003. Material Irregularities: A guide for registered auditors and accountants. Out of circulation. 
Palmrose, Z.-V. 1988. AN ANALYSIS OF AUDITOR LITIGATION AND AUDIT SERVICE QUALITY. The Accounting Review, 63, 55.

Palmrose, Z.-V. 1997. Audit litigation research: Do the merits matter? An assessment and directions for future research. Journal of Accounting and Public Policy, 16, 355-378.

Parker, L. \& Roffey, B. 1997. Methodological Themes. Back to the drawing board: revisiting grounded theory and the everyday accountant's and manager's reality. Accounting, Auditing and Accountability Journal, 10, 212-247.

Peecher, M. E., Schwartz, R. \& Solomon, I. 2007. It's all about audit quality: Perspectives on strategicsystems auditing. Accounting, Organizations and Society, 32, 463-485.

Pentland, B. T. 1993. Getting comfortable with the numbers: Auditing and the micro-production of macroorder. Accounting, Organizations and Society, 18, 605-620.

Pentland, B. T. 2000. Will auditors take over the world? Program, technique and the verification of everything. Accounting, Organizations and Society, 25, 307-312.

Pesqueux, Y. 2005. Corporate governance and accounting systems: a critical perspective. Critical Perspectives on Accounting, 16, 797-823.

Powell, W. 2010. Does auditor tenure affect accounting conservatism? Further evidence. Journal of Accounting and Public Policy, 29, 226-241.

Powell, W. W. 2007. The New Institutionalism. 2007. Available: http://www.stanford.edu/group/song/papers/NewInstitutionalism.pdf [Accessed 17 October 2011].

Power, M. 1995. Auditing, Expertise and the Sociology of Technique. Critical Perspectives on Accounting, 6, 317-339.

Power, M. 1997. Expertise and the construction of relevance: Accountants and environmental audit. Accounting, Organizations and Society, 22, 123-146.

Power, M. K. 1994. The Audit Explosion, London, Demos.

Power, M. K. 2003. Auditing and the production of legitimacy. Accounting, Organizations and Society, 28, 379-394.

PwC. 2006. Reportable irregularities. Available: http://www.pwc.co.za/en/publications/index.jhtml [Accessed 10 November 2009].

PwC. 2009a. Kings Counsel. Available: < http://www.pwc.com/za/en/king3/index.jhtml> [Accessed 30 November 2011].

PwC. 2009b. Steering Point: King III. Available: http://www.pwc.com/za/en/publications/steeringpoint.jhtml [Accessed 30 November 2011].

PwC. 2011a. Cybercrime: protecting against the growing threat. Global Economic Crime Survey. Available: http://www.pwc.com/en_GX/gx/economic-crimesurvey/assets/GECS_GLOBAL_REPORT.pdf [Accessed 30 November 2011].

PwC. 2011b. Whislteblowing: The importance of speaking up. Available: http://www.pwc.com/en_GX/gx/ifrs-reporting/pdf/world-watch-issue-2-2011-interactive.pdf [Accessed 30 November 2011].

Quattrone, P. \& Hopper, T. 2005. A 'time-space odyssey': management control systems in two multinational organisations. Accounting, Organizations and Society, 30, 735-764.

Reckers-Sauciuc, A. K. \& Lowe, D. J. 2010. The influence of dispositional affect on whistle-blowing. Advances in Accounting, 26, 259-269.

Riotto, J. J. 2008. Understanding the Sarbanes-Oxley Act--A valued added approach for public interest. Critical Perspectives on Accounting, 19, 952-962.

Rodrigues, L. L. \& Craig, R. 2007. Assessing international accounting harmonization using Hegelian dialectic, isomorphism and Foucault. Critical Perspectives on Accounting, 18, 739-757.

Rotter, J. 1966. Generalized expectancies for internal vs. external control of reinforcement. Psychological monographs, 1-28.

Rowley, J. 2012. Conducting research interviews. Management Research Review, 35, 260-271.

SAICA 2012. CODE OF PROFESSIONAL CONDUCT FOR CHARTERED ACCOUNTANTS.

Seifert, D. L., Sweeney, J. T., Joireman, J. \& Thornton, J. M. 2010. The influence of organizational justice on accountant whistleblowing. Accounting, Organizations and Society, 35, 707-717. 
Shaked, A. \& Sutton, J. 1981. The Self-Regulating Profession. Review of Economic Studies, 48, 217-234.

Sikka, P. A., Puxty, H. W. \& Cooper, C. 1992. Eliminating the Expectations Gap?

Solomon, J. 2009. Directions for Corporate Governance. In: ACCA (ed.). London: Certified Accountants Educational Trust.

Solomon, J. 2010. Corporate Governance and Accountability, Third Edition, West Susex, United Kingdom, John Wiley and Sons Ltd.

Staub, E. 1978. Positive Social Behavior and Morality: Social and Personal Influences, New York Academic Press, Vol. 1 No.95, pp189-225.

Suchman, M. C. 1995. Managing Legitimacy: Strategic and Institutional Approaches. The Academy of Management Review, 20, 571-610.

Sy, A. \& Tinker, T. 2008. Sarbanes-Oxley: An endangered specie? Critical Perspectives on Accounting, 19, 927-930.

Unerman, J. \& O'Dwyer, B. 2004. Enron, WorldCom, Andersen et al.: a challenge to modernity. Critical Perspectives on Accounting, 15, 971-993.

Vakkur, N. V., McAfee, R. P. \& Kipperman, F. 2010. The unintended effects of the Sarbanes-Oxley Act of 2002. Research in Accounting Regulation, 22, 18-28.

van Esch, S., Negash, M., Firer, S., Oosthuizen, T., Abdol-Samad, T., Padia, N. \& Patron, S. 2004. International Audit Quality Control Standards: A South African Persepctive. Report to the Public Accountans' \& Auditors' Board Johannesburg, South Africa: University of the Witwatersrand, School of Accountancy

Vecchiatto, P. 2011. Busa appeals for public interest defence in bill [Online]. Johannesburg. Available: http://www.businesslive.co.za/southafrica/2011/11/22/busa-appeals-for-public-interest-defence-inbill [Accessed 23 November 2011].

Ventovuori, T., Lehtonen, T., Salonen, A. \& Nenonen, S. 2007. A review and classification of academic research in facilities management. Facilities, 25, 227-237.

Vinten, G. 2000. Perspectives: Whistleblowing towards quality. Total Quality Management, 12, 166-171.

Vinten, G. 2003. Whistleblowing: the UK experience. Management Decision, 41, 935-943.

Watts, R. L. \& Zimmerman, J. L. 1983. Agency Problems, Auditing, and the Theory of the Firm: Some Evidence. Journal of Law and Economics, 26, 613-633.

Wielligh, P. V. 2006. Irregularities: Material or Reportable? Accountancy SA, April, 10-13.

Windsor, C. \& Warming-Rasmussen, B. 2009. The rise of regulatory capitalism and the decline of auditor independence: A critical and experimental examination of auditors' conflicts of interests. Critical Perspectives on Accounting, 20, 267-288.

Windsor, C. A. \& Ashkanasy, N. M. 1995. The effect of client management bargaining power, moral reasoning development, and belief in a just world on auditor independence. Accounting, Organizations and Society, 20, 701-720.

Wines, G. 2012. Auditor independence: Shared meaning between the demand and supply sides of the audit services market? Managerial Auditing Journal, 27, 5-40.

Wyatt, A. R. 2004. Accounting Professionalism-They Just Don't Get It! Accounting Horizons, 18, 45.

Zeff, S. A. 2003a. How the U.S. accounting profession got where it is today: Part I. Accounting Horizons, $17,189$.

Zeff, S. A. 2003b. How the U.S. Accounting Profession Got Where It Is Today: Part II. Accounting Horizons, 17, 267.

Zucker, L. 1986. Production of Trust: Institutional Sources of Economic Structure, 1840-1920. Research in Organizational Behaviour, 8, 53-11. 